Copyright (C) 2021 University of Bucharest Printed in Romania. All rights reserved

ISSN print: $1224-5984$

ISSN online: $2248-3942$
Rom Biotechnol Lett. 2021; 26(4): 2773-2778 doi: $10.25083 / \mathrm{rbl} / 26.4 / 2773.2778$

Received for publication, March, 16, 2020

Accepted, May, 11, 2020

Original paper

\title{
Effect of ethanolic extract of Silybum marianum L. Gaertn. on Iipid peroxidation inhibition and microbial count in minced beef
}

\author{
WALEED GAMAL EL DIN FAHMY ${ }^{2}$, SAHAR RAMADAN ABDELHADY ${ }^{1}$, \\ SAMIR MAHMOUD METWALY ${ }^{2}$ and FATMA ALI AHMED ${ }^{1}$
}

${ }^{1}$ Food Technology Department, Faculty of Agric., Kafr El Sheikh Univ., Egypt

${ }^{2}$ Medicinal and Aromatic Plants Department, Desert Research Center, Cairo, Egypt

\begin{abstract}
The present research was carried out for two main targets, the first one is phytochemical and biological screening of the aerial parts of Silybum marianum. The second one is the possibility of using Silybum marianum ethanolic extract as natural preservative for extending minced beef shelf-life during refrigeration and frozen storage. The chemical analysis of dry matter revealed that total ash content was $13.04 \%$ of D.M, crude fibers, total phenolic compounds, total flavonoids and total tannins were $(24.59 \%, 9.16 \%, 0.84 \%$ and $(0.08 \%)$, respectively. The highest values of antioxidant activity were recorded in ethyl acetate and ethyl alcohol $70 \%$ extacts, respectively for successive and selective solvents with values of $82.45 \%$ and $58.85 \%$ for successive solvents, $86.84 \%$ and $70.50 \%$ for selective solvents, respectively. Antimicrobial activity showed that, S. marianum L. Gaertn. had effect on gram positive, gram negative bacteria and yeast but had no effect on different strains of studied fungi. S. marianum had an influence on microorganisms growth in minced beef, the highest effect was $1.0 \%$ for 60 days (56 CFU). The most effective concentrations on lipid peroxidation prevention in minced beef were $1.5 \%$ for 3 days and 1.5 for 60 days.
\end{abstract}

Keywords Antioxidant, microorganisms count, Silybum, TBA.

To cite this article: EL DIN FAHMY WG, ABDELHADY SR, METWALY SM, ALI AHMED F. Effect of ethanolic extract of Silybum marianum L. Gaertn. on lipid peroxidation inhibition and microbial count in minced beef. Rom Biotechnol Lett. 2021; 26(4): 2773-2778. DOI: $10.25083 / \mathrm{rbl} / 26.4 / 2773-2778$

$\triangle$ *Corresponding author: WALEED GAMAL EL DIN FAHMY, Medicinal and Aromatic Plants Department, Desert Research Center, Cairo, Egypt

E-mail: wagadifa1990@gmail.com 


\section{Introduction}

Genus Silybum which belongs to the tribe Asterales of the Asteraceae family is originally located in Middle East, Arabian peninsula, the Indian subcontinent, North Africa and parts of Europe. It has been presented to Japan, African sub-Saharan, North and South America, parts of Europe, Australia and New Zealand (USDA, 2013). Silybum marianum, recognized as milk thistle, is an old therapeutic plant which used from early eras as plant extract for remedy of different illnesses such as liver and gallbladder complaints (LAYLAH et al, 2012). The past literature showed that, the German Commission E indorses its use mainly for indigestion symptoms and liver conditions, including toxin-induced liver damage and hepatic cirrhosis, and as a helpful therapy for chronic inflammatory liver conditions (BLUMENTHAL and BUSSE, 1998). In the United States, milk thistle is one of the greatest commonly sold herbal products. Patients anticipate milk thistle in a diversity of medical situations, but it is widely used in gastrointestinal health centers to help handle hepatitis and cirrhosis. Despite a scarcity of quantifiable trials inspecting the security of milk thistle in the oncology set, studies have found that, milk thistle is one of the most frequently given hepatoprotectives among people with cancer. Patients and physicians stated using milk thistle to assist the liver in detoxification, forestalling that milk thistle may aid eliminate toxins from the blood and potentially help them in enduring cancer treatment. This perception was originally projected in a situation study and has afterward been maintained by one experimental trial that was done between children with acute lymphoblastic leukemia (LADAS, et al, 2007). One stage 3 clinical trial in adult men with prostate cancer stated postponements in expanding prostate specific antigen levels compared with control (SCHRODER et al, 2005).

As we know bacterial based diseases are the most significant infectious illnesses. So, the researchers have begun for achieving new antibacterial drugs obtained from different sources in more than 50 years of experiments. Regardless of the development and enhancement of antimicrobial agents, there are still specific demands to discover new antibacterial drugs due to the increase of drug-resistant bacteria (WISE et al, 1998). Oliveira et al., (2015) reported that, silibinin as the main constituent of silymarin showed slight inference against the bacterial strains tested. Silybin displayed a marvelous synergistic action when mixed with some antibacterial agents against drug-resistant bacteria. Therefore, silybin has a thinkable part as a combination therapeutic agent against multidrugresistant bacteria (JUNG and LEE, 2008).

No previous applied work has been done on different extracts of S. marianum aerial part in Egypt up to now. The present research was carried out for two main targets, the first one is phytochemical and biological screening of the aerial parts of Silybum marianum. The second one is the possibility of using Silybum marianum ethanolic extract as natural preservative for extending minced beef shelf-life during refrigeration and frozen storage for improving its hygienic quality by determine thiobarbituric acid-reactive substances and its microbiological contents in fresh and stored samples.

\section{Materials and Methods}

\section{Materials gathering and documentation of samples}

Arial parts of $S$. marianum L. Gaertn. plant was collected during two years 2016 and 2017 from El- Kasr region, Matrouh Governorate in April during flowering season. Then, cleaned, dried in an oven at $60^{\circ} \mathrm{C}$ for 48 hours and ground to fine powder. For further investigation a twenty gram of air-dried plant powder were refluxed with $250 \mathrm{ml}$ of $80 \%$ ethyl alcohol using soxhlet apparatus for about 6 hours, then filtered. The combined filtrates were concentrated under reduced pressure at $50^{\circ} \mathrm{C}$ using rotary vacuum evaporator, and then used for tests. The samples were identified and authenticated in the herbarium of Flora Department, Agriculture Research Center, by Sherif El Khanagry. Voucher specimens were deposited in Desert Research Center (DRC) herbarium.

\section{Determination of proximate analysis}

The proximate composition (moisture, crude fiber, ash content) of powder sample of aerial parts of $S$. marianum was determined according to the methods described by A.O.A.C. (2005).

2.1. Determination of carbohydrates content: Total, soluble and insoluble carbohydrates were determined in plant samples according to the method outlined by Chaplin and Kennedy (1994).

2.2. Crude protein content: Total nitrogen content was determined using Microkjeldahl method according to British Pharmacopoeia (1993). using Velp Scientifica, UDK 149 Automatic Kjeldahl Distillation Unit - fisher scientific - UK.

\section{Determination of total phenolic compounds}

The concentrations of total polyphenols in each extract were determined as tannic with Folin-Ciocalteau reagent (GUTFINGER, 1981). An aliquot of the extract $(0.1 \mathrm{ml})$ was diluted with water to $5 \mathrm{ml}$ in $10 \mathrm{ml}$ volumetric flask, then $0.5 \mathrm{ml}$ of Folin-Ciocalteau reagent was added after $3 \mathrm{~min}$. One $\mathrm{ml}$ of saturated sodium carbonate $\mathrm{Na}_{2} \mathrm{CO}_{3}$ solution was added. The mixture was homogenized and diluted to $10 \mathrm{ml}$ volume with distilled water. The absorption was measured using spectrophotometer (Thermo UVVisible Spectrophotometer - USA - supplied with Thermo Scientific VISION pro software) after $1 \mathrm{hr}$ at $760 \mathrm{~nm}$ against a blank sample. Tannic acid was served as a standard compound and used for the preparation of calibration curve in the range from 0 to $10 \mathrm{ppm}$. 


\section{Determination of total flavonoids and tannins}

The total flavonoids were determined as quercetin using UV spectrophotometer (Thermo UV-Visible Spectrophotometer - USA - supplied with Thermo Scientific VISION pro software) as described by Karawaya and Aboutabl (1982). Total tannins were estimated according to Balbaa (1986).

\section{In vitro antioxidant activity using DPPH assay}

The antioxidant activities of different extracts of S. marianum were determined by the 2, 2-diphenyl-1,1picrylhydrazyl (DPPH) free radical scavenging assay according to the method of Burits and Bucar (2000) by measuring the optical density with (Thermo UV-Visible Spectrophotometer - USA - supplied with Thermo Scientific VISION pro software).

\section{Antimicrobial activity of $S$. marianum L. Gaertn. extracts}

6.1. Micro-organisms bacterial and fungi strains: The microorganisms were obtained from Plant Pathology and Microbiology Department, National Research Center, Doki, Cairo. Four bacterial strains were tested, Bacillus subtilis (ATCC6633), Staphylococcus aureus (ATCC25923), Pseudomonas aeruginosa (ATCC27583) and Escherichia coli (PTCC1037). The fungal strains used were Aspergillus niger, Aspergillus fumagatus and Fusarium oxysporum. The yeast strain was Candida albicans (PTCC1023).

6.2. Agar diffusion method: Agar diffusion method was used to check the presence or absence of antimicrobial agents as described by Booth (1972).

\section{Determination of antimicrobial activity of} S. marianum L. Gaertn. in minced beef

The meat samples were homogenized with S. marianum $70 \%$ ethanolic extract with concentrations $[0.5,1.0$ and $1.5 \%(\mathrm{v} / \mathrm{w})]$ Each sample was packed in polyethylene bag, labeled and stored at $4^{\circ} \mathrm{C}$ for 14 days. The samples were analyzed promptly at 3 days intervals during storage as recommended by APHA (1992).

\section{Determination of thiobarbituric acid (TBA) reactive substances in minced beef}

Lipid oxidation was measurement by determine the thiobarbituric acid-reactive substances (TBARS) using the method described by Zeb and Ullah (2016). In a $10 \mathrm{~mL}$ test tube, $1 \mathrm{~mL}$ of Malondialdehyde standard solution, $1 \mathrm{~mL}$ TBA solution was mixed. With a boiling water bath at $95^{\circ} \mathrm{C}$ (GFL - Germany) the mixture was heated for 60 minutes, then cooled at room temperature and absorbance was measured and repeated $(n=3)$ for each standard and a blank sample at $532 \mathrm{~nm}$ using (Thermo UVVisible Spectrophotometer - USA - supplied with Thermo Scientific VISION pro software). A blank sample was prepared by using acetic acid or water instead of standard or sample. The same procedure was carried on the extract of each sample and repeated three times $(n=3)$.

\section{Statistical Analysis}

The data were subjected to statistical analysis using the MSTATC software version no. 10 (Michigan State University, Michigan, USA). Differences between samples were determined by one-way analysis of variance (ANOVA) followed by Duncan's multiple range test. $\mathrm{P}$ value of $<0.05$ was considered statistically significant.

\section{Results and Discussion}

\section{Proximate analysis and total active materials}

In this study the contents of water content, ash, crude fiber, total flavonoids and tannins of $S$. marianum L. Gaertn. plant were determined to evaluate its ability to adapt itself to severe conditions of wild habitat.

Data represented in Table 1 revealed that, the highest chemical composition of $S$. marianum plants was crude fiber $(24.59 \%)$, meanwhile, the least chemical composition recorded for total tannins was $(0.08 \%)$. The results from the proximate analysis also showed that, $S$. marianum aerial parts were high in crude fiber content. In the same manner, the results showed that, total ash is relatively high. These results are in harmony with those found by (APOSTOL et al, 2017, EL-HAAK, et al, 2015, GHAFOR et al, 2014, SULAS et al, 2016).

Table 1. Proximate analysis of dry matter of $S$. marianum plants.

\begin{tabular}{lccc}
\hline Item & $\%$ & Item & $\%$ \\
\hline Moisture content & $65.80 \pm 1.00$ & Crude fibers & $24.59 \pm 3.05$ \\
Carbohydrates & $53.25 \pm 2.00$ & Total flavonoids & $0.84 \pm 0.05$ (as quercetin) \\
Crude protein & $8.75 \pm 1.05$ & Total phenolics & $9.16 \pm 1.20$ (as tannic acid) \\
Total ash & $13.04 \pm 1.05$ & Total tannins & $0.08 \pm 0.05$ (as gallic acid) \\
\hline
\end{tabular}

Nutritionally, this is of beneficial effect since it had been reported that, food fiber aids absorption of trace elements in the gut and reduce absorption of cholesterol (ABOLAJI et al, 2007). Ash content $(13.04 \%)$ is a reflection of the mineral contents preserved in the plant. Minerals are essential for the proper functioning of tissues and act as second messenger in some biochemical cascade mechanisms (ANITA et al, 2006). Also, the data in Table 1 revealed that, the percentage of total flavonoids and total tannins were 0.84 and 0.08 , respectively in aerial partsof $S$. marianum. These results are in harmony with the results found by (MHAMDI et 
al, 2016). Tannins are used in the treatment of wounds emanating from varicose ulcers and hemorrhoids (NJOKU and AKUMUFULA, 2007), it is also used to stop bleeding during circumcision. Flavonoids are immense medical values; it possesses antioxidant and antiinflammatory activity. It has the ability to scavenge hydroxyl radicals, superoxide anions and lipid peroxyl radicals (OKWU and JOSIAH, 2006).

\section{In vitro antioxidant activity DPPH assay}

The data in Table 2 revealed that, the highest values of antioxidant activity were water and ethyl alcohol $70 \%$ extracts, respectively. The values were 86.84 and 70.50 , respectively. The results were nearly similar to those found by (MHAMDI et al, 2016 and SULAS et al, 2016).

Table 2. Antioxidant activity percentage of Silybum marianum using DPPH method

\begin{tabular}{ll}
\hline Extract $(1000 \mu \mathrm{g} / \mathrm{ml})$ & Scavenging $\%$ \\
\hline Ethyl acetate & $26.10 \pm 1.92$ \\
Ethyl alcohol $70 \%$ & $70.50 \pm 2.32$ \\
Water & $86.84 \pm 3.15$ \\
Gallic Acid & $91.43 \pm 1.41$ \\
\hline
\end{tabular}

Antioxidant properties, particularly radical scavenging power, are very important because of the harmful action of free radicals in foods and biological systems (TAWAHA et al, 2007). DPPH molecule which is containing a stable free radical has been broadly used to estimate the radical scavenging capability of antioxidant.

The free radical scavenging potentiality of the three extracts, i.e. ethyl acetate, ethyl alcohol $70 \%$ and water were also examined by using DPPH. In this study results showed that, DPPH radical scavenging power of the extracts were low than those of gallic acid (Table 2).

According to (MILLER, 1971), ethanolic extracts may contain phenolic and hydroxy phenolic compounds with acid, alcohol, sugar or glycoside and portion of the antioxidative action may be due to these components or flavonoids. In other studies, the DPPH scavenging abilities of extracts were different from each other and also from ours. These differences might have been derived from local, climatic and seasonal factors (YAMAGUCHI et al, 2000).

\section{Antimicrobial activity of Silybum marianum}

The data in Table 3 , shows the potential antimicrobial activity of $S$. marianum, where different extracts were subjected to certain strains of microorganisms to estimate inhibition growth power for the tested organisms. These results were in similarity with (AHMAD et al, 2015 and DONG GUN et al, 2003), where $S$. marianum different extracts demonstrated high antibacterial activities.

Table 3. Antimicrobial activity of Silybum marianum different extracts

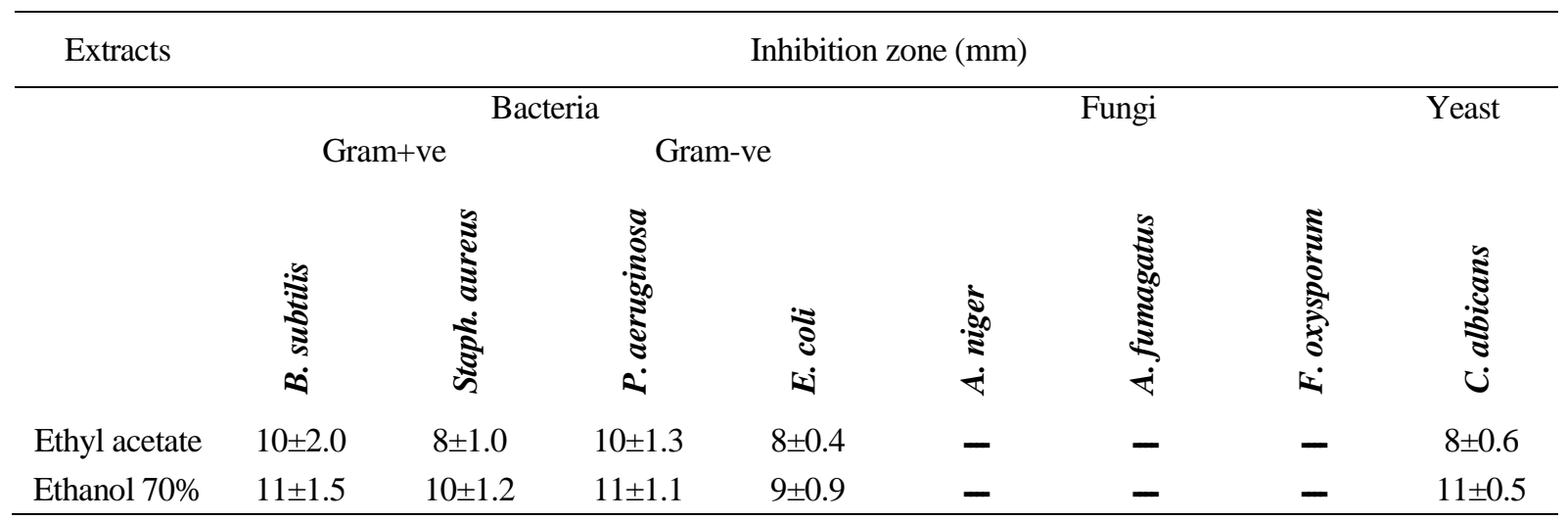

The antimicrobial activity of the plant may be due to the presence of flavonoids. Flavonoids have been shown to have antimicrobial, anti-inflammatory, antiallergic, antimutagenic, antiviral, antineoplastic, anti-thrombotic and vascodilatory activity (ALAN and MILLER, 1996). Furthermore, Kchaou et al. (2016) found that the highest resistance in Gram negative bacteria might be explained by the presence of their outer membrane covering the cell wall which limits the diffusion of hydrophilic compounds through its lipopolysaccharide coating. The absence of this brazier at the Gram positive bacteria allows the direct contact of the hydrophobic compounds with their phospholipids bilayer of the cell membrane which cause an increase in permeability and leakage of intracellular compounds vital, as the reduction of the bacterial enzyme system. However, most studies have reported that plants 
extracts generally are more active against the Gram positive bacteria than the Gram negative ones.

\section{Determination of antimicrobial activity of ethanolic extract of $S$. marianum in minced beef \\ Table 4 revealed that, ethanolic extract of S. marianum had an influence on microorganisms' growth in minced beef. It is obvious that, the highest effect was $0.5 \%$ for 30 days and 3 days ( 40 and $80 \mathrm{CFU}$ ), respectively. The lowest effect was 15 days with $1.0 \%$ and 90 days with $1.5 \%$ (320 and $224 \mathrm{CFU}$ ), respectively. This may be due to the high phenolic and flavonoid content of S. marianum.}

\section{Effect of ethanolic extract on lipid peroxidation in minced beef}

In Table 5, data represent the most effective concentration on lipid peroxidation prevention in minced beef was $1.5 \%$ for 3 days and the least one was $1.5 \%$ for 15 days. These results may be explained by direct free radical scavenging capability which has been reported in many in vitro experiments. This capability is due to the high concentration of phenolic and flavonoids (mainly silibinin and silydianin) in 70\% ethanolic extract which are well known with the ability of ending the free radical chain reaction (SURAI, 2015).

Table 4. Determination of antimicrobial activity of 70\% ethanolic extract of S. marianum in minced beef

\begin{tabular}{|c|c|c|c|c|c|c|c|c|c|c|c|c|}
\hline \multirow{4}{*}{ Samples } & \multicolumn{12}{|c|}{ Aerobic plat count $\left(\mathrm{CFU} \times 10^{3}\right)$} \\
\hline & \multirow{2}{*}{\multicolumn{2}{|c|}{3 days }} & \multirow{2}{*}{\multicolumn{2}{|c|}{$\begin{array}{l}\text { Refrigeration } \\
7 \text { days }\end{array}$}} & \multirow{2}{*}{\multicolumn{2}{|c|}{15 days }} & \multirow{2}{*}{\multicolumn{2}{|c|}{30 days }} & \multirow{2}{*}{\multicolumn{2}{|c|}{$\begin{array}{c}\text { Freezing } \\
60 \text { days }\end{array}$}} & \multirow{2}{*}{\multicolumn{2}{|c|}{90 days }} \\
\hline & & & & & & & & & & & & \\
\hline & B & $\mathrm{Y}$ & B & $\mathrm{Y}$ & B & $\mathrm{Y}$ & B & $\mathrm{Y}$ & B & $\mathrm{Y}$ & B & $\mathrm{Y}$ \\
\hline Control & $76.0^{1}$ & $52.0^{\mathrm{e}}$ & $980.0^{\mathrm{a}}$ & $96.0^{\mathrm{d}}$ & $48.0^{\mathrm{m}}$ & $120.0^{c}$ & $32.0^{\mathrm{n}}$ & $8.0^{1}$ & $56.0^{\mathrm{m}}$ & $16.0^{\mathrm{i}-1}$ & $100.0^{\mathrm{j}}$ & $48.0^{\mathrm{ef}}$ \\
\hline $0.5 \%$ & $400.0^{b}$ & $12.0 \mathrm{k}^{1}$ & $120.0^{\mathrm{i}}$ & $40.0 \mathrm{f}^{\mathrm{y}}$ & $160.0^{\mathrm{h}}$ & $320.0^{\mathrm{a}}$ & $92.0^{\mathrm{jk}}$ & $32.0^{\text {gh }}$ & $228.0^{\text {ef }}$ & $32.0^{\mathrm{gh}}$ & $208.0^{\mathrm{g}}$ & $20.0^{\mathrm{h}-\mathrm{I}}$ \\
\hline $1.0 \%$ & $80.0 \mathrm{k}^{1}$ & $40.0 \mathrm{f}^{\mathrm{g}}$ & $316.0^{c}$ & $30.0^{\mathrm{gh}}$ & $320.0^{c}$ & $160.0^{\mathrm{b}}$ & $128.0^{\mathrm{i}}$ & $28.0^{\mathrm{g}-\mathrm{i}}$ & $56.0^{\mathrm{m}}$ & $20.0^{\mathrm{h}-1}$ & $128.0^{\mathrm{i}}$ & $11.3^{1}$ \\
\hline $1.5 \%$ & $120.0^{\mathrm{i}}$ & $24.0^{\mathrm{h}-\mathrm{k}}$ & $256.0^{\mathrm{d}}$ & $14.0^{\mathrm{j}-1}$ & $240.0^{\mathrm{e}}$ & $40.0^{\mathrm{fg}}$ & $204.0^{\mathrm{g}}$ & $24.7^{\mathrm{h}-\mathrm{j}}$ & $216.0^{\mathrm{fg}}$ & $8.0^{1}$ & $224^{\mathrm{f}}$ & $24^{\mathrm{h}-\mathrm{k}}$ \\
\hline
\end{tabular}

$\mathrm{CFU}=$ Colony Forming Unit, $\mathrm{B}=$ bacteria, $\mathrm{Y}=$ yeast, $\mathrm{F}=$ fungi Data are the average of three experiments. Control (untreated sample) Culture condition: $\mathrm{pH} 7$ and, temperature $36^{\circ} \mathrm{C}$.

Table 5. Estimated values of TBA $(\mathrm{mg} / \mathrm{kg})$ for lipid peroxidation in minced beef using S. marianum $70 \%$ ethanolic extract

\begin{tabular}{|c|c|c|c|c|c|c|}
\hline \multirow{3}{*}{ Conc } & \multicolumn{6}{|c|}{ Time } \\
\hline & \multicolumn{3}{|c|}{ Refrigeration } & \multicolumn{3}{|c|}{ Freezing } \\
\hline & 3 Days & 7 Days & 15 Days & 30 Days & 60 Days & 90 Days \\
\hline BHA & $20.45^{\mathrm{hi}}$ & $25.24 \mathrm{e}^{\mathrm{fg}}$ & $20.62^{\mathrm{hi}}$ & $38.80^{\mathrm{b}}$ & $23.64^{\text {fgh }}$ & $16.58^{\mathrm{j}}$ \\
\hline Control & $40.80^{\mathrm{d}-\mathrm{f}}$ & $47.56^{\mathrm{c}-\mathrm{f}}$ & $42.04^{\mathrm{c}-\mathrm{f}}$ & $30.93^{\text {ef }}$ & $71.24^{\mathrm{b}}$ & $44.98^{\mathrm{c}-\mathrm{f}}$ \\
\hline $0.5 \%$ & $41.02^{c-f}$ & $98.27^{\mathrm{a}}$ & $44.93^{\mathrm{c}-\mathrm{f}}$ & $33.24^{\mathrm{ef}}$ & $91.91^{\mathrm{a}}$ & $56.40^{\mathrm{b}-\mathrm{d}}$ \\
\hline $1.0 \%$ & $32.98^{\text {ef }}$ & $43.51^{\mathrm{c}-\mathrm{f}}$ & $71.38^{\mathrm{b}}$ & $35.20^{\text {ef }}$ & $39.55^{\mathrm{d}-\mathrm{f}}$ & $60.58^{\mathrm{bc}}$ \\
\hline
\end{tabular}

TBA = Thiobarbutric acid (mg malonaldhyde/Kg sample)

\section{Conclusion and Recommendations}

Under the experimental conditions of this study, the results obtained suggest that the highest chemical composition of $S$. marianum plants was crude fiber. Meanwhile, the highest values of antioxidant activity were water and ethyl alcohol $70 \%$ extracts. On the other hand, ethanolic extract of $S$. marianum had an influence on microorganisms' growth in minced beef; the highest effect was $0.5 \%$ for 30 days and 3 days. The most effective concentration on lipid peroxidation prevention in minced beef was $1.5 \%$ for 3 days.

\section{Conflicts of Interest}

The authors declare that there are no conflicts of interest.

\section{Acknowledgments}

The authors would like to thank Ms/ Manar A. El Agoury, microbiologist for her help in microbial count.

\section{References}

1. A.P.H.A., 1992. Standard methods for the examination of dairy products. fifteenth ed. New York: American Public Health Association.

2. ABOLAJI, O.A., ADEBAYO, A.H., ODESANMI, O.S., 2007. Nutritional qualities of three medicinal plant parts (Xylopia aethiopica, Blighia sapida and Parinari polyandra) commonly used by pregnant women in the western part of Nigeria. Pak. J. Nutr. 6, 665-68.

3. AHMAD, N., PERVEEN, R., JAMIL, M., NAEEM, R., ILYAS, M., 2015. Comparison of antimicrobial Properties of Silybum marianum (L) Collected from Ten Different Localities of Khyber Pakhtunkhwa Pakistan and Diversity Analysis Through RAPDs Pattern. Int. J. of Plant Sci. and Ecol. 1, 241-45.

4. ALAN, L., MILLER, N.D., 1996. Antioxidant flavonoids: structure, function and clinical usage. Alt. Med. Rev. 1, 103-11. 
5. ANITA, B.S., AKPAN, E.J., OKON, P.A., UMOREN, I.U., 2006. Nutritive and anti-nutritive evaluation of sweet potatoes (Impomoea batatas) leaves. Pak. J. Nut. 5, 166-68.

6. APOSTOL, L., IORGA, C.S., MOȘOIU, C., MUSTĂȚEA, G., CUCU, Ș., 2017. Nutrient composition of partially defatted milk thistle seeds. Sci. bull. Series F. Biotechnol. XXI, 165-72.

7. BALBAA, S.I., 1986. Chemistry of Crude Drugs. Laboratory Manual. Faculty of Pharmacy, Cairo University.

8. BLUMENTHAL, M., BUSSE, W.R., editors., 1993. The complete german commission E monographs: Therapeutic guide to herbal medicines. Austin, Tex.: American Botanical Council; 1998.

9. BOOTH, D.A., 1998. Conditioned satiety in the rat. J. of Comp. Physiol. and Psychol. 81, 457-71.

10. British pharmacopoeia, 1993. Published on the Recommendation of the Medicines Commission Pursuant to the Medicines Act 1968. HMSO.

11. BURITS, M., BUCAR, F., 2000. Antioxidant activity of Nigella sativa essential oil. Phytother. Res. 14, 323-28.

12. CHAPLIN, M.F., KENNEDY, J.F., 1994. Carbohydrate analysis, a practical approach. $2^{\text {nd }}$ ed. USA: Oxford Univ Press.

13. DE OLIVEIRA, D.R., TINTINO, S.R., BRAGA, M.F.B.M., BOLIGON, A.A., ATHAYDE, M.L., COUTINHO, H.D.M., DE MENEZES, I.R.A., FACHINETTO, R., 2015. In vitro antimicrobial and modulatory activity of the natural products silymarin and silibinin. Biomed. Res. Int. 292797, Pp7.

14. DONG GUN, L., HYUNG KEUN, K., YOONKYUNG, P., SEONG-CHEOL, P., EUN-RHAN, W., HYE GWANG, J., KYUNG-SOO, H., 2003. Gram-positive bacteria specific properties of silybin derived from Silybum marianum. Arch. Pharm. Res. 26, 597-600.

15. EL-HAAK, M.A., ATTA, B.M., ABD RABO, F.F., 2015. Seed yield and important seed constituents for naturally and cultivated milk thistle (silybum marianum) plants. The Egypt. Soc. of Exp. Biol. 11, 141-46.

16. GHAFOR, Y., MOHAMMAD, N.N., SALH, D.M., 2014. Extraction and determination of chemical ingredients from stems of Silybum Marianum. Chem. and Mater. Res. 6,26-32.

17. GUTFINGER, T., 1981. Polyphenols in olive oils. J.A.O.C.S. 58, 966-68.

18. Jung, H.J., Lee, D.G., 2008. Synergistic antibacterial effect between silybin and N,N'-dicyclohexylcarbo diimide in clinical Pseudomonas aeruginosa isolates. J. Microbiol. 46, 462-67.

19. KARAWAYA, M.S., ABOUTABL, E.A., 1982. Phytoconstituents of Tabernaemontana coronaria Jac. Q. Willd and Dichotoma roxb growing in Egypt. Part IV: The flavonoids. Bulletin of Fac. Of Pharm. Cairo Univ. XXI, 41-49.

20. KCHAOU, W., ABBÈS, F., MANSOUR, R.B., BLECKER, C., ATTIA, H., \& BESBES, S., 2016. Phenolic profile, antibacterial and cytotoxic properties of second grade date extract from Tunisian cultivars
(Phoenix dactylifera L.). Food chemistry, 194, 10481055.

21. LADAS, E., GREENLEE, H., ABASCAL, K., YARNELL, E., 2007. Clinical applications of Silybum marianum in oncology. THER. 6, 158-165.

22. LAYLAH, Z.F., MEZIANI, M., MAZA, A., 2012. Silymarin natural antimicrobiol agent extracted from Silybum Marianum. J. Acad. 2, 164-9.

23. MHAMDI, B., ABBASSI, F., ABDERRAZAK, S., ABDELLY, C., MARZOUK, B., 2016. Fatty acids, essential oil and phenolics composition of Silybum marianum seeds and their antioxidant activities. Pak. J. Pharm. Sci. 29, 951-59.

24. MILLER, H.E., 1971. A simplified method for the evaluation of antioxidants. J. Am. Oil. Chem. Soc. 48, 91-105.

25. NJOKU, P.C., AKUMUFULA, M.I., 2007. Phytochemical and nutrient evaluation of Spondias mombin leaves. Pak. J. Nutr. 6, 613-15.

26. Official methods of analysis, 2005. Association of Official Analytical Chemists. $18^{\text {th }}$ Edition. Washington, DC.USA.

27. OKWU, D.E., JOSIAH, C., 2006. Evaluation of the chemical composition of two Nigerian medicinal plants. Afr. J. Biotechnol. 5, 357-61.

28. SCHRÖDER, F.H. ROOBOL, M.J., BOEVÉ, E.R., DE MUTSERT, R., ZUIJDGEEST-VAN LEEUWEN, S.D., KERSTEN, I., WILDHAGEN, M.F., VAN HELVOORT, A., 2005. A randomized, double-blind, placebo-controlled crossover study in men with prostate cancer and rising PSA: Effectiveness of a dietary supplement. Eur. Urol. 48, 922-30.

29. SUlAS, L., GIOVANNI, A.RE., BULlitTA, S., PILUZZA, G., 2016. Chemical and productive properties of two Sardinian milk thistle (Silybum marianum (L.) Gaertn.) populations as sources of nutrients and antioxidants. Genet. Resour. Crop. Evol. 63, 315-26.

30. SURAI, P.F., 2015. Silymarin as a natural antioxidant: An overview of the current evidence and perspectives. Antioxid. 4, 204-47

31. TAWAHA, K., ALALI, F.Q., GHARAIBEH, M., MOHAMMAD, M., EL ELIMAT, T., 2007. Antioxidant activity and total phenolic content of selected Jordanian plant species. Food Chem. 104, 1372-78.

32. USDA, NRCS., The plants database, National Plant Data Center, Baton Rouge, LA 70874-4490 USA. Available at (http://plants.usda.gov). Accessed March 6, 2018.

33. WISE, R., HART, T., CARS, O., STREULENS, M., HELMUTH, R., HUOVINEN, P., SPRENGER, M., 1998. Antimicrobial resistance. Is a major threat to public health. B.M.J. 5, 609-10.

34. YAMAGUCHI, F., ARIGA, T., YOSHIMURA, Y., NAKAZAWA, H., 2000. Antioxidative and antiglycation activity of garcinol from Garcinia indica fruit rind. J. of Agric. Food Chem. 48, 180-85.

35. ZEB, A., ULLAH, F.A., 2016. simple spectrophotometric method for the determination of thiobarbituric acid reactive substances in fried fast foods. J. of Anal. Methods in Chem. Article ID 9412767, Pp5. 